\title{
Influence of NPK Fertilization and Wild Oat (Avena fatua) Densities on Wheat Crop
}

\author{
Fakkar, A.A.; A.E. Ismail and Nadia M. Hemeid* \\ Weed Research Central Laboratory, Agric. Res. Center, Giza, Egypt. \\ "Soils, Water and Environ. Res. Inst., Agric. Res. Center, Giza, Egypt.
}

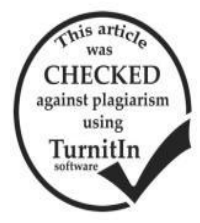

ABSTRACT

Two field experiments were conducted at Shandaweel Agricultural Research Station, Sohag Governorate during two growing winter seasons 2013/2014 and 2014/2015. The objective of this work was to study the effect of NPK fertilizer levels and wild oat competition on wheat productivity. Each experiment included eighteen treatments which were the combination of three NPK fertilizer levels being $50 \mathrm{~kg} \mathrm{~N}-10 \mathrm{~kg} \mathrm{P}_{2} \mathrm{O}_{5}-12 \mathrm{~kg} \mathrm{~K}_{2} \mathrm{O}$ fed $^{-1}, 75 \mathrm{~kg} \mathrm{~N}-15 \mathrm{~kg} \mathrm{P}_{2} \mathrm{O}_{5}-24 \mathrm{~kg} \mathrm{~K}_{2} \mathrm{O}$ fed ${ }^{-1}$ and $100 \mathrm{~kg} \mathrm{~N}-20 \mathrm{~kg} \mathrm{P} \mathrm{O}_{5}$ $-36 \mathrm{~kg} \mathrm{~K}_{2} \mathrm{O} \mathrm{fed}^{-1}$ and six of wild oat densities i.e., zero, 5, 10, 15, 20 and 25 wild oat plant $\mathrm{m}^{-2}$. A split plot design, with four replications was used. Results revealed that increasing NPK rates increased significantly the studied wheat growth parameters, yield and its components in both seasons. Application of $\mathrm{N}_{75} \mathrm{P}_{15} \mathrm{~K}_{24}$ and $\mathrm{N}_{100} \mathrm{P}_{20} \mathrm{~K}_{36}$ fertilizer levels increased grain yield by 8.7 and $17.4 \%$, respectively in the first season and 10.1 and $19.2 \%$, respectively in the second season compared to the lowest $\left(\mathrm{N}_{50} \mathrm{P}_{10} \mathrm{~K}_{12}\right)$ fertilizer rate. Also, increasing NPK fertilizer rates had significant effect on most of $\mathrm{N}, \mathrm{P}$ and $\mathrm{K} \%$ of both wheat and wild oat plants at 30,60 and 90 days after sowing (DAS). N, P and K \% decreased with growth in both wheat and wild oat plants and were higher with wild oat than wheat in $\mathrm{N} \%$ showing that wild oat plants is a great competitor with wheat plants for $\mathrm{N}$ nutrient. Moreover, the addition of NPK fertilizer levels significantly affected N, P and K \%, NPK uptake and protein \% in wheat grain. Application of $\mathrm{N}_{75} \mathrm{P}_{15} \mathrm{~K}_{24}$ and $\mathrm{N}_{100} \mathrm{P}_{20} \mathrm{~K}_{36}$ increased protein $\%$ in grain wheat by 9.7 and $12.9 \%$, respectively in the first season and 9.5 and $11.2 \%$, respectively in the second season compared to the lowest $\left(\mathrm{N}_{50} \mathrm{P}_{10} \mathrm{~K}_{12}\right)$ fertilizer rate. In contrary, increasing wild oat density $\mathrm{m}^{-2}$ caused adverse effect on wheat growth, yield and its components in both seasons. Increasing number of wild oat plants from 5 to $25 \mathrm{~m}^{-2}$ reduced the grain yield by 6.1 to $25.0 \%$, in the first season and 8.5 to $28.3 \%$, in second season compared with wild oat free treatment. Positive significant effects were detected for wild oat density $\mathrm{m}^{-2}$ on $\mathrm{N}, \mathrm{P}$ and $\mathrm{K}$ percentage of both wheat and wild oat plants at 30,60 and $90 \mathrm{DAS}$ as well as wheat grain contents of N, P, K and protein in both seasons. Increasing wild oat plants from 5 to $25 \mathrm{~m}^{-2}$ decreased grain protein \% from 0.9 to $17.4 \%$, in $2013 / 14$ and from 2.4 to $8.9 \%$, in $2014 / 15$ compared with wild oat free plots. The interaction between $\mathrm{N}_{100} \mathrm{P}_{20} \mathrm{~K}_{36}$ fertilization rate and zero wild oat plants $\mathrm{m}^{-2}$ gave the highest wheat grain yield $\left(22.93\right.$ and 24.23 ard.fed $\left.{ }^{-1}\right)$ in the $1^{\text {st }}$ and $2^{\text {nd }}$ seasons, respectively compared with $\mathrm{N}_{50} \mathrm{P}_{10} \mathrm{~K}_{12}$ fertilization rate and 25 wild oat plants $\mathrm{m}^{-2}\left(15.10\right.$ and $\left.15.03 \mathrm{ard}_{\text {.fed }}{ }^{-1}\right)$ in the $1^{\text {st }}$ and $2^{\text {nd }}$ seasons, respectively. From this study, we can conclude that the integration between $\mathrm{N}_{100} \mathrm{P}_{20} \mathrm{~K}_{36}$ fertilization and zero wild oat plants $\mathrm{m}^{-2}$ gave the highest wheat grain yield and protein.

Keywords: NPK fertilization, wild oat density, wheat, growth, yield and yield components

\section{INTRODUCTION}

Wheat (Triticum aestivum L.) is the most important cereal crop in the world and the main food crop in Egypt where a great gap between the consumption and production is exist. Increasing wheat production could be possible via both horizontal expansion through increasing the cultivated area with wheat and vertical expansion through the development of new cultivars having the high potentiality and subsequently implementing the proper cultural practices as NPK fertilization and weed management especially wild oat in the infested soils.

Fertilizer plays an important role in increasing wheat grain yield. The proper amount of NPK fertilizer application is considered a key to the large crop production (Tariq et al., 2007). Many studies have shown that, in some cases, fertilizers benefit weeds more than crops. For example, Carlson and Hill (1985) found that the addition of $\mathrm{N}$ fertilizer to wild oatinfested wheat increased the density of wild oat panicles and reduced the wheat grain yield. Mohammaddoust et al., (2006) found that fertilizer management may be a means of reducing weed interference in crops. Khan et al., (2007) noted that nitrogen levels $(75,100$ and 125 $\mathrm{kg} \mathrm{ha}^{-1}$ ) gave significant effect on the number of spikes $\mathrm{m}^{-2}$, spike length $(\mathrm{cm})$, grains spike ${ }^{-1}, 1000$ grain weight $(\mathrm{g})$, tiller wild oat ${ }^{-1}$, number of seed tiller ${ }^{-1}$ of wild oat and grain yield $\left(\mathrm{kg} \mathrm{ha}^{-1}\right)$. Laghari et al., (2010) reported that fertilizer application significantly enhanced growth, yield and nutrient uptake traits of wheat. Application of 120-60-60 NPK kg ha ${ }^{-1}$ recorded maximum tillers, spike length, grains spike $^{-1}$, biological yield, grain yield, harvest index, dry matter, leaf area index, crop growth rate and NPK uptake. Malghani et al., (2010) concluded that the highest grain yield $\mathrm{Kg} \mathrm{ha}^{-1}$ was recorded with the application of $175-150-125 \mathrm{NPK} \mathrm{Kg} \mathrm{ha}{ }^{-1}$. The increase in yield was $51.58 \%$ higher as compared to control, where no fertilizer was used. Shahram et al., (2011) stated that the negative effect of wild oat on wheat grain yield increased with increasing nitrogen application. Also, under high wild oat infestations resultant to decrease nitrogen efficiency on wheat plant agronomy i.e. spikes area unit ${ }^{-1}$, grain $\mathrm{spike}^{-1}$ and 1000grain weight.

On the other hand, wild oat is considered as a serious compete weed of wheat crop in Egypt. Wild oat was described as a vigorously growing weed with a capability to attain greater height, and establish and develop extensive leaf area and horizontal branches when moisture and nutrients are not limiting (Dhima and Eleftherohorinos, 2001). The morphological and physiological characteristics of wild oat allow it to shade and suppress the growth of its neighbors to a level that causes yield reduction (Cudney et al., 1991). Makowski (1995) reported that increasing the densities of wild oats decreased the competitiveness of wheat cultivars. Kirkland (1993) showed that wild oat density of 64 and 118 plants $\mathrm{m}^{-2}$ reduced wheat grain yields by $28 \%$ and $39 \%$, respectively. Ibrahim et al., (1995) in 
pot experiments, indicated that the density patterns (wheat + wild oat) by $6+6,6+5,6+4,6+3,6+2$ and $6+1$ compared with 6 wheat plant only decreased grain yield plant $^{-1}$ by 58, 54, 48, 43, 16 and $7 \%$, respectively in $1^{\text {st }}$ season and by $54,38,22,38,16$ and 7 $\%$, respectively in $2^{\text {nd }}$ season. They also, found that densities decreased significantly plant height, plant weight, spike length, spike number and spike weight in both seasons. AL-Marsafy et al., (1995) found that the reduction in wheat grain yield due to wild oat infestation is attributed to the reduction in number of spikes plant ${ }^{-1}$ and spikes weight plant ${ }^{-1}$. Walia et al., (1998) concluded that wheat yield decreased exponentially when wild oats populations varied from 0 to 100 plants $\mathrm{m}^{-2}$ and the loss approached to $50-60 \%$ at 100 plants of wild oats $\mathrm{m}^{-2}$. Harrison et al., (2001) stated that linear response range at low densities of wild oat and maximum yield loss of $90 \%$ at high wild oat densities were found. This indicates that wild oat attained its maximum growth earlier than wheat. Silvertown and Charlesworth (2001) reported $30 \%$ yield reduction in wheat crop with a wild oat density of 120 plants $\mathrm{m}^{-2}$. Ahmadvand et al., (2002) studied the effect of four wild oat plant densities $(0,30,50$ and 80 plants $\mathrm{m}^{-2}$ ) on growth, yield and yield components of wheat. The results showed that wheat dry weight, grain yield, the number of tillers and spikes per unit area, and wheat 1000-grain weight declined as wild oat plant density increased. Wheat yield was described well by a linear regression model, using both absolute plant density and relative biomass of wild oat or using the relative density of wild oat in the weed-crop stand. Mennan (2003) indicated that the percentage of wheat yield losses was correlated to the weed density using a linear regression model for wild oat. The economic thresholds of wild oat were between 11.77 and 14.70 plants $\mathrm{m}^{-2}$. Mennan and Bozoglu (2004) found that grain yield and dry weight per plant were decreased by increasing wild oat density from 20, 40, 80, and 160 plants $\mathrm{m}^{-2}$. Khan and Hassan (2006) noted that wild oats densities at $0,5,10,15,20,25$ and 30 seed $\mathrm{m}^{-2}$ decreased the number of spikes $\mathrm{m}^{-2}$, spike length $(\mathrm{cm})$, grains spike ${ }^{-1}, 1000$ grain weight $(\mathrm{g})$, tiller wild oat ${ }^{-1}$, number of seed tiller ${ }^{-1}$ of wild oat and grain yield $\left(\mathrm{kg} \mathrm{ha}{ }^{-1}\right)$. Cheema and Akhtar (2006) revealed that Avena fatua $L$ grown in association with wheat caused an average yield reduction of 4.61, 7.27, 12.51, 17.45 and 21.24 percent in grain yield at weed density of 5, $10,15,20$ and 25 wild oat plants $\mathrm{m}^{-2}$, respectively as compared to weed free check. The various yield components of wheat like fertile tillers $\mathrm{m}^{-2}$, number of grains spike ${ }^{-1}$ and 1000 -grain weight were significantly reduced due to the increase in wild oat density. Hassan and Khan (2007), Khan et al., (2007) and Khan et al., (2008) showed that the highest number of spikes $\mathrm{m}^{-2}$, grains spike ${ }^{-1}$ and 1000-grain weight were recorded in wheat monocultures ( 0 wild oat density plot). Also, they found that one wild oat plant $\mathrm{m}^{-2}$ inflicted $1 \%$ reduction in wheat yield. Increasing of wild oat densities from 0 , $10,20,30$, and 40 plants $\mathrm{m}^{-2}$ caused reduction in grain protein content. El- Nass (2010) found that increasing wild oat densities up to $25,50,100$ and 200 plants $\mathrm{m}^{-2}$ decreased grain yield by $9.83,19.80,39.89$ and 60.53 $\%$, respectively in the first season. The respective decrements in the second season were 8.01, 21.03, 34.48 and $61.66 \%$. Polynomial quadratic regression showed close correlation relationship between grain yield ton ha ${ }^{-1}$ and wild oat densities in the two seasons. It also, showed that at $5 \%$ acceptable yield losses (AYL) the economic threshold were 10.76 and 11.08 plants $\mathrm{m}^{-2}$ in the two seasons, respectively. Khan et al., (2007) found that less than 1 wild oat plant $\mathrm{m}^{-2}$ inflicted a $1 \%$ reduction in wheat yield, while a $30 \%$ reduction in yield was predicted with the infestation of 15,17 , and 16 wild oat plants $\mathrm{m}^{-2}$ under 75,100 , and $125 \mathrm{~N} \mathrm{~kg} \mathrm{ha}^{-1}$ fertilizer regimes.

Thus, the objective of this work is to investigate the effect of wild oat densities on wheat yield productivity under NPK fertilization in Sohag Governorate.

\section{MATERIALS AND METHODS}

Two field experiments were conducted in heavily and natural infested soil with wild oat (Avena fatua) at Shandaweel Agricultural Research Station, Sohag Governorate in the two successive seasons 2013/14 and 2014/15. This experiment aimed to study the effect of wild oat densities on wheat growth and yield productivity under NPK fertilization. Soil analysis of the experimental plots in both seasons is shown in (Table 1) according to the procedures by Jackson (1973). In this study, variety sids "12" (Triticum aestivum L.) was used tested and the preceding summer crop was sorghum (Sorghum bicolor $L$ Moench) in both seasons. The sowing dates were $28^{\text {th }}$ and $22^{\text {nd }}$ of November in the first and the second seasons, respectively. The other normal agricultural practices of wheat growing in the region were done. Seeding rate was $60 \mathrm{~kg} \mathrm{fed}^{-1}$ with Afir drill method (dry method). The experiment was laid out in split plot arrangement with four replications. Plot area was $4 \mathrm{~m}^{2}(2.0 \mathrm{~m} \times 2.0 \mathrm{~m})$.

Each experiment included eighteen treatments, which were the combination of three rates NPK of fertilizers added in the main plots and six wild oat densities allocated in sub plots as follows.

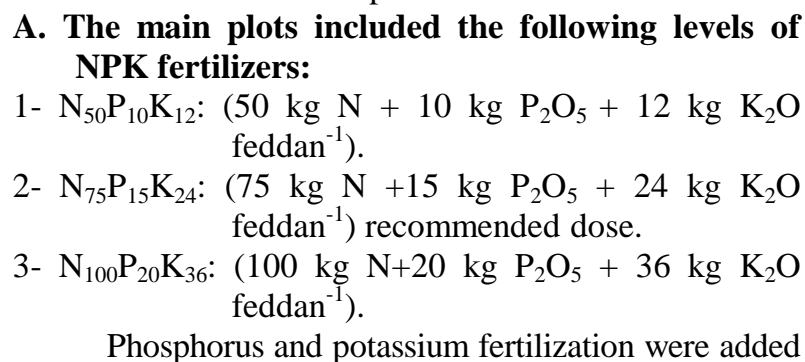
as calcium superphosphate $\left(15.0 \% \mathrm{P}_{2} \mathrm{O}_{5}\right)$ and potassium sulphate $\left(\begin{array}{lll}48.0 & \% & \mathrm{~K}_{2} \mathrm{O}\end{array}\right)$, respectively during land preparation before planting. Meanwhile, nitrogen fertilizer was added in the form of urea $(46.0 \% \mathrm{~N})$ in two doses where $40 \%$ of nitrogen fertilizer was broadcasted uniformly at the sowing and the rest of amount $(60 \%)$ was added immediately before first irrigation.

B- The sub plots included six wild oat densities namely:

1- Zero wild oat plants $\mathrm{m}^{-2}$ (wild oat free). 
2- 5 wild oat plants $\mathrm{m}^{-2}$.

3- 10 wild oat plants $\mathrm{m}^{-2}$.

4- 15 wild oat plants $\mathrm{m}^{-2}$.

5- 20 wild oat plants $\mathrm{m}^{-2}$.

6- 25 wild oat plants $\mathrm{m}^{-2}$ (as maximum natural

infestation level in experimental field).
After twenty days from sowing, annual broadleaved, grassy weeds and zero wild oat had been removed by hand-pulling biweekly intervals.

Table 1. Physical and chemical properties of the experimental soil in 2013/14 and 2014/15 seasons.

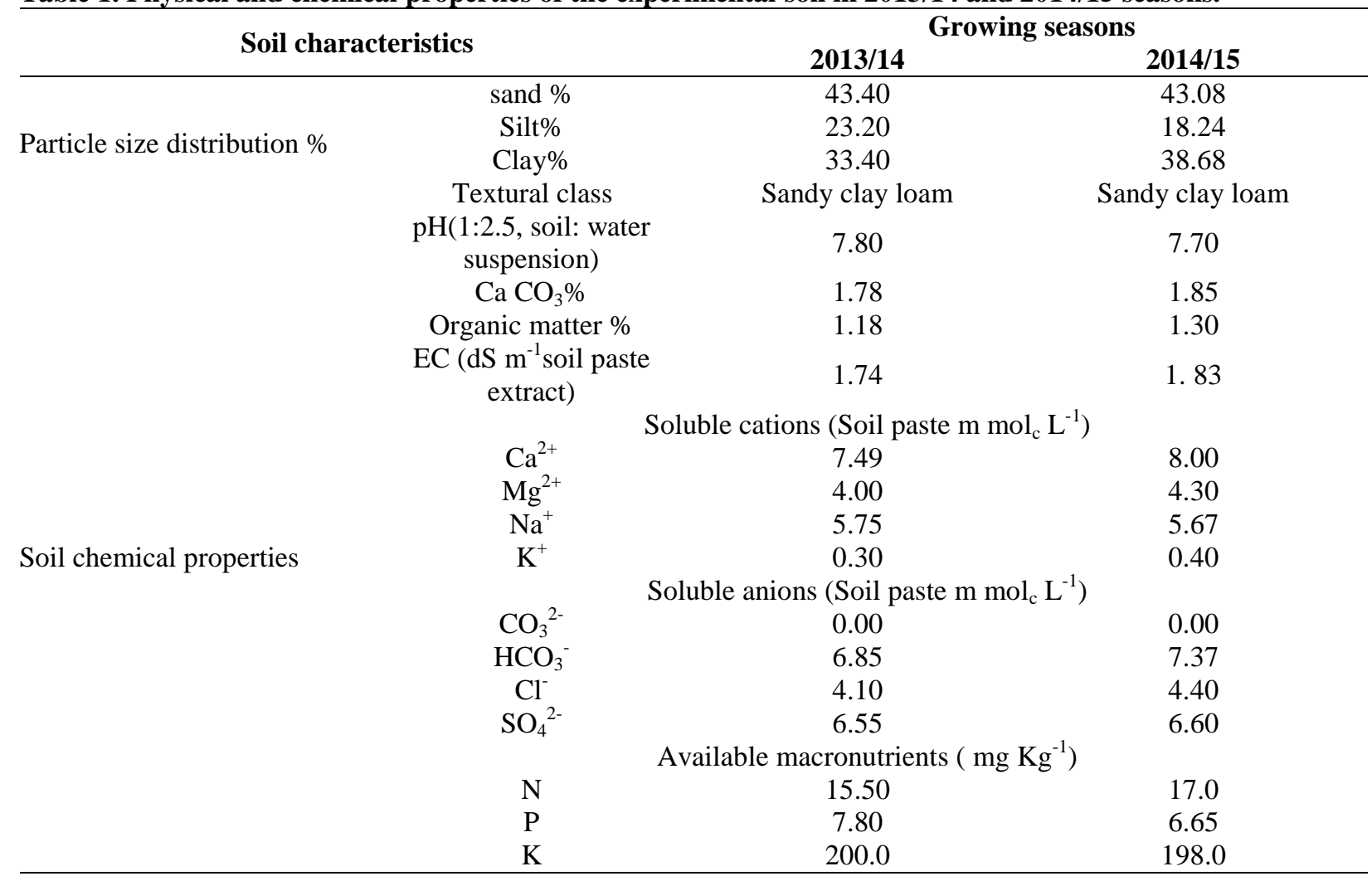

\section{Data recorded:}

A- Dry weight of wheat $\mathrm{m}^{2}$ :

A sample of wheat were taken randomly from one square meter from each plot at 80 and 120 days after sowing and dried at $70{ }^{\circ} \mathrm{C}$ for 48 hours (till constant weight), and dry weight was determined.

\section{B-Yield and yield components:}

At harvest, ten guarded wheat plants were hand pulled randomly from each plot to estimate plant height (cm), number of tillers plant ${ }^{-1}$, number of spikes $\mathrm{m}^{-2}$, number of grains spike ${ }^{-1}$, weight of grains $\operatorname{spike}^{-1}(\mathrm{~g})$, 1000-grain weight $(\mathrm{g})$ and all plants of the whole plot were harvested to estimate the grain yield $\left(\operatorname{ard} . \mathrm{fed}^{-1}\right)$ ard. $=$ ardab $=140 \mathrm{~kg}$ grains.

\section{C- Chemical analyses:}

At 30, 60 and 90 days after sowing, two plants from wild oat and wheat were chosen randomly from each plot and oven dried at $70{ }^{\circ} \mathrm{C}$ over night to determine nitrogen, phosphorus and potassium $\%$ in dry matter of wheat and wild oat plants.

At harvest, grain samples were also dried in forced oven at $70 \mathrm{C}$, and all samples were then ground and wet digested using concentrated sulfuric acid and mixture of $\mathrm{H}_{2} \mathrm{SO}_{4}$ and perchloric acids (1:1) for oxidation (A.O.A.C. 1990) to determined nutrient concentrations. Total nitrogen was determined using the standard procedure of micro- Kjeldhal method as described by Black (1965). Crud protein percent in wheat grains was calculated by multiplying the total nitrogen in wheat meal by 5.7 according to Tkachuk (1966). Phosphorus (\%) was determined colourieterically according to (Jackson, 1973). Potassium (\%) was determined by flame photometer as described by Jackson (1973). NPK taken up in wheat grains was calculated by multiplying NPK concentration by dry wheat of grain yield feddan ${ }^{-1}$.

\section{Statistical Analysis:}

Statistical analysis was carried out according to Gomez and Gomez (1984) using MSTAT-C computer software (Freed et al., 1989). The means values were compared at $5 \%$ level of significance by using L.S.D test. For regression study data were plotted and regression analyses were conducted. Linear $\tilde{y}=a+b x$, quadratic $\tilde{y}=a+b x-c x^{2}$ and $\operatorname{logstic} \tilde{y}=a+b x+c x^{2}+d x^{3}$ models were estimated to describe the relationship between the measured dependent variable wild oat density (no. $\mathrm{m}^{-2}$ ) and independent variables wheat grain yield $\left(\operatorname{ard} . f e d^{-1}\right)$. Whereas, $\tilde{y}=$ variables, $X=$ wild oat density, a, b, c and d parameters represent intercept and slope of regression of variables and a regression models. The suitable model which fitted for prediction between mentioned above variables quadratic regression analysis according to Snedecor and Cochran (1989) which is the correlation coefficient $\left(\mathrm{R}^{2}\right)$ was greater than other studied 
models and standard estimate error (SE) were smaller than those of the models.

\section{RESULTS AND DISCUSSION}

\section{1- Wheat growth characteristics: Effect of NPK fertilizers.}

The obtained data in Table (2) reveal that wheat dry weight of plants at 80 or 120 days after sowing (DAS), plant height and number of tillers plant ${ }^{-1}$ were significantly increased by increasing NPK levels from $\mathrm{N}_{50} \mathrm{P}_{10} \mathrm{~K}_{12}$ up to $\mathrm{N}_{100} \mathrm{P}_{20} \mathrm{~K}_{36}$ in both seasons. The incident increases due to the highest level $\left(\mathrm{N}_{100} \mathrm{P}_{20} \mathrm{~K}_{36}\right)$ compared to the lowest level reached 57.5 and $54.0 \%$ for wheat dry weight at 80 DAS and 21.1 and $24.9 \%$ for wheat dry weight at 120 DAS, and 8.8 and $10.7 \%$ for plant height and 20.6 and $16.2 \%$ for number of tillers plant ${ }^{-1}$ during the first and second seasons, respectively. This finding showed that extra dose of NPK had increased the growth of wheat in terms of dry weight of plant, plant height and number of tillers plant ${ }^{-1}$ which lead to increased competitive ability of wheat against wild oat weed. These results were in harmony with those obtained by Mohammad oust et al., (2006) and Laghari et al., (2010).

Table 2. Effect of NPK fertilizer rates and wild oat densities on wheat plant growth characteristics in 2013/2014 and 2014/2015 seasons.

\begin{tabular}{|c|c|c|c|c|}
\hline Treatments & $\begin{array}{c}\text { Wheat dry weight at } 80 \\
\text { DAS }\left(\mathrm{gm}^{-2}\right)\end{array}$ & $\begin{array}{c}\text { Wheat dry weight at } \\
120 \text { DAS }\left(\mathrm{gm}^{-2}\right)\end{array}$ & $\begin{array}{c}\text { Plant height }(\mathrm{cm}) \text { at } \\
\text { harvest }\end{array}$ & $\begin{array}{c}\text { No. of tillers plant } \\
\text { at harvest }\end{array}$ \\
\hline \multicolumn{5}{|c|}{$2013 / 2014$ season } \\
\hline \multicolumn{5}{|c|}{ A - NPK fertilizer } \\
\hline $\mathrm{N}_{50} \mathrm{P}_{10} \mathrm{~K}_{12}$ & 488.9 & 1341.9 & 102.3 & 2.52 \\
\hline $\mathrm{N}_{75} \mathrm{P}_{15} \mathrm{~K}_{24}$ & 607.4 & 1460.1 & 108.1 & 2.68 \\
\hline $\mathrm{N}_{100} \mathrm{P}_{20} \mathrm{~K}_{36}$ & 770.2 & 1624.8 & 111.3 & 3.04 \\
\hline L.S.D. at 0.05 & 11.8 & 25.8 & 3.1 & 0.10 \\
\hline \multicolumn{5}{|c|}{ B - Wild oats densities $\mathrm{m}^{-2}$} \\
\hline Zero & 757.4 & 1658.4 & 114.8 & 2.99 \\
\hline 5 & 714.5 & 1570.2 & 110.6 & 2.89 \\
\hline 10 & 643.7 & 1519.0 & 108.9 & 2.80 \\
\hline 15 & 586.2 & 1434.4 & 107.2 & 2.71 \\
\hline 20 & 539.0 & 1360.6 & 103.3 & 2.60 \\
\hline 25 & 492.2 & 1310.7 & 98.7 & 2.50 \\
\hline L.S.D. at ${ }_{0.05}$ & 17.2 & 34.9 & 4.9 & 0.09 \\
\hline \multicolumn{5}{|c|}{$2014 / 2015$ season } \\
\hline \multicolumn{5}{|c|}{ A - NPK fertilizer } \\
\hline $\mathrm{N}_{50} \mathrm{P}_{10} \mathrm{~K}_{12}$ & 592.6 & 1448.8 & 103.8 & 2.59 \\
\hline $\mathrm{N}_{75} \mathrm{P}_{15} \mathrm{~K}_{24}$ & 789.1 & 1674.3 & 109.0 & 2.88 \\
\hline $\mathrm{N}_{100} \mathrm{P}_{20} \mathrm{~K}_{36}$ & 912.8 & 1809.3 & 114.9 & 3.01 \\
\hline L.S.D. at 0.05 & 11.7 & 54.2 & 3.8 & 0.06 \\
\hline \multicolumn{5}{|c|}{ B - Wild oats densities $\mathrm{m}^{-2}$} \\
\hline Zero & 857.1 & 1807.7 & 116.0 & 3.09 \\
\hline 5 & 828.5 & 1738.1 & 111.6 & 3.04 \\
\hline 10 & 783.2 & 1678.9 & 110.6 & 2.89 \\
\hline 15 & 744.8 & 1606.9 & 108.4 & 2.81 \\
\hline 20 & 706.3 & 1549.9 & 106.2 & 2.67 \\
\hline 25 & 669.1 & 1483.4 & 102.9 & 2.56 \\
\hline L.S.D. at 0.05 & 27.3 & 30.5 & 5.9 & 0.10 \\
\hline \multicolumn{5}{|c|}{ Interactions } \\
\hline $\mathrm{A} \times \mathrm{B}_{2013 / 2014}$ & 29.7 & 60.5 & NS & NS \\
\hline $\mathrm{A} \times \mathrm{B}_{2014 / 2015}$ & 47.2 & 52.8 & NS & 0.17 \\
\hline
\end{tabular}

Effect of wild oat density.

Statistical analysis of data in Table (2) indicated that wild oat densities $\mathrm{m}^{-2}$ had significant effects on dry weight of wheat plant at 80 or 120 DAS, plant height and number of tillers plant ${ }^{-1}$ in both seasons. The densities of $5,10,15,20$ and 25 wild oats $\mathrm{m}^{-2}$ reduced dry weight of wheat plants at 80 DAS by 5.7, 15.0, 22.6, 28.8 and $35.0 \%$, respectively compared to zero wild oat in the first season. At 120 DAS less reduction in wheat dry matter was recorded due to wild oat densities at 5 , $10,15,20$ and 25 plants $\mathrm{m}^{-2}$ which reduced dry weight of wheat plants by $5.3,8.4,13.5,18.0$ and $21.0 \%$, respectively in the first season compared to zero wild oat. In the second season the reduction in dry weight of wheat plants at 80 DAS due to 5, 10, 15, 20 and 25 plants $\mathrm{m}^{-2}$ was $3.3,8.6,13.1,17.6$ and $21.9 \%$, respectively compared to zero wild oat. At 120 DAS, wild oat densities at $5,10,15,20$ and 25 plants $\mathrm{m}^{-2}$ reduced dry weight of wheat plants by $3.9,7.1,11.1$, 14.3 and $17.9 \%$, respectively in the second season compared to zero wild oat.

At harvest time, it was noticed that the tallest wheat plant $114.8 \mathrm{~cm}$ in the first season and $116.0 \mathrm{~cm}$ in the second season was observed in weed free treatment 
but the shortest wheat plant $\left(98.7 \mathrm{~cm}\right.$ in $1^{\text {st }}$ season and $102.9 \mathrm{~cm}$ in $2^{\text {nd }}$ season) was recorded with the density of 25 wild oat plants $\mathrm{m}^{-2}$. The highest number of tillers plant $^{-1}$ (2.99 and 3.09 in the first and second seasons, respectively) was recorded in weed free treatment and the lowest number of tillers plant ${ }^{-1}(2.50$ and 2.56 in the first and second seasons, respectively) was observed in the density of 25 wild oat plants $\mathrm{m}^{-2}$. The cause of this decline can be related to the high ability of this weed to absorb nutrients and increases vegetative growth and the limitation of wheat growth space, increase of shadowing and the rise in wheat tillers mortality (Carlson and Hill, 1985). These results are in accordance with Ibrahim et al., (1995), Ahmadvand et al., (2002) and Mennan and Bozoglu (2004)

\section{Yield and yield components:}

\section{Effect of NPK fertilizer.}

The results of Table (3) illustrate that increasing $\mathrm{N}, \mathrm{P}$ and $\mathrm{K}$ rates significantly enhanced wheat grain yield and its components. Both $\mathrm{N}_{75} \mathrm{P}_{15} \mathrm{~K}_{24}$ and $\mathrm{N}_{100} \mathrm{P}_{20} \mathrm{~K}_{36}$ induced significant increase over low rate $\left(\mathrm{N}_{50} \mathrm{P}_{10} \mathrm{~K}_{12}\right)$ in favor of the highest rate which gave 27.4 and $30.4 \%$ increase in number of spikes $\mathrm{m}^{-2}, 15.3$ and $10.9 \%$ in number of grain spike ${ }^{-1}, 30.1$ and $41.5 \%$ in grain weight spike ${ }^{-1}$, and 3.4 and $5.9 \%$ in 1000- grain weight during the first and second seasons, respectively. The same trend was observed with grain yield which was significantly increased by 8.7 and $17.4 \%$ over the low rate due to $\mathrm{N}_{75} \mathrm{P}_{15} \mathrm{~K}_{24}$ and $\mathrm{N}_{100} \mathrm{P}_{20} \mathrm{~K}_{36}$, respectively in the first season and 10.1 and $19.2 \%$, respectively in the second season. It is clear that the previous increases were due to increasing NPK fertilizers which increased number of tillers plant ${ }^{-1}$, number of spikes $\mathrm{m}^{-2}$, number of grains spike ${ }^{-1}$, grain weight spike $^{-1}, 1000$-grain weight and grain yield feddan ${ }^{-1}$. Zimdahl (2004) found that the rise in fertilizers consumption especially nitrogen increase the crop yield and improve the crop compatibility with the weeds. However, the addition of nutrient elements influenced the weed growth more than the crop when weed density is high. These results are in line with Carlson and Hill (1985), Khan et al., (2007), Laghari et al., (2010), Malghani et al., (2010) and Shahram et al., (2011).

Table 3. Effect of NPK fertilizer rates and wild oat densities on yield and yield components of wheat in 2013/2014 and 2014/2015 seasons.

\begin{tabular}{|c|c|c|c|c|c|}
\hline Treatments & $\begin{array}{c}\text { No. of } \\
\text { spikes } \mathbf{~ m}^{-2}\end{array}$ & $\begin{array}{c}\text { No. of } \\
\text { Grains Spike }^{-1}\end{array}$ & $\begin{array}{l}\text { Grains weight } \\
\text { Spike }^{-1}(\mathrm{~g})\end{array}$ & $\begin{array}{c}\text { 1000- Grain } \\
\text { weight (g) }\end{array}$ & $\begin{array}{l}\text { Grain yield } \\
\left.\text { (ard. fed }^{-1}\right)\end{array}$ \\
\hline \multicolumn{6}{|c|}{$2013 / 2014$ season } \\
\hline \multicolumn{6}{|c|}{ A- NPK fertilizer } \\
\hline $\mathrm{N}_{50} \mathrm{P}_{10} \mathrm{~K}_{12}$ & 345.3 & 45.0 & 2.92 & 46.6 & 17.21 \\
\hline $\mathrm{N}_{75} \mathrm{P}_{15} \mathrm{~K}_{24}$ & 421.3 & 47.3 & 3.14 & 47.9 & 18.70 \\
\hline $\mathrm{N}_{100} \mathrm{P}_{20} \mathrm{~K}_{36}$ & 440.0 & 51.9 & 3.80 & 48.2 & 20.20 \\
\hline L.S.D at ${ }_{0.05}$ & 18.5 & 1.97 & 0.63 & 0.51 & 0.68 \\
\hline \multicolumn{6}{|c|}{ B- Wild oats densities $\mathrm{m}^{-2}$} \\
\hline Zero & 435.1 & 49.7 & 3.8 & 48.5 & 21.20 \\
\hline 5 & 420.0 & 49.1 & 3.7 & 48.2 & 19.90 \\
\hline 10 & 405.0 & 48.1 & 3.2 & 48.0 & 18.84 \\
\hline 15 & 401.3 & 47.7 & 3.2 & 47.5 & 17.90 \\
\hline 20 & 381.0 & 47.2 & 3.0 & 47.0 & 16.95 \\
\hline 25 & 370.8 & 46.5 & 2.7 & 46.1 & 15.90 \\
\hline L.S.D at ${ }_{0.05}$ & 13.28 & 0.86 & 0.33 & 0.68 & 2.51 \\
\hline \multirow{2}{*}{\multicolumn{6}{|c|}{$\begin{array}{l}\text { 2014/2015 season } \\
\text { A- NPK fertilizer }\end{array}$}} \\
\hline & & & & & \\
\hline $\mathrm{N}_{50} \mathrm{P}_{10} \mathrm{~K}_{12}$ & 358.5 & 46.6 & 3.06 & 47.5 & 17.34 \\
\hline $\mathrm{N}_{75} \mathrm{P}_{15} \mathrm{~K}_{24}$ & 444.3 & 48.5 & 3.82 & 48.7 & 19.09 \\
\hline $\mathrm{N}_{100} \mathrm{P}_{20} \mathrm{~K}_{36}$ & 467.5 & 51.7 & 4.33 & 50.3 & 20.66 \\
\hline L.S.D at ${ }_{0.05}$ & 21.3 & 1.59 & 0.55 & 0.59 & 0.64 \\
\hline \multicolumn{6}{|c|}{ B- Wild oats densities $\mathrm{m}^{-2}$} \\
\hline Zero & 451.3 & 50.4 & 4.4 & 50.7 & 21.89 \\
\hline 5 & 421.4 & 49.9 & 4.2 & 49.9 & 20.04 \\
\hline 10 & 419.6 & 49.2 & 3.9 & 49.3 & 18.76 \\
\hline 15 & 402.0 & 48.4 & 3.6 & 48.5 & 17.59 \\
\hline 20 & 389.6 & 47.9 & 3.4 & 47.8 & 16.57 \\
\hline 25 & 370.7 & 47.1 & 3.0 & 46.9 & 15.69 \\
\hline L.S.D at ${ }_{0.05}$ & NS & 0.69 & 0.26 & 0.49 & 2.04 \\
\hline \multicolumn{6}{|c|}{ Interactions } \\
\hline $\mathrm{A} \times \mathrm{B}_{2013 / 2014}$ & 63.0 & NS & NS & NS & 0.44 \\
\hline $\mathrm{A} \times \mathrm{B}_{2014 / 2015}$ & 123.0 & NS & 0.47 & 0.84 & 0.54 \\
\hline
\end{tabular}

\section{Effect of wild oat density.}

Data in Table (3) showed that number of spikes $\mathrm{m}^{-2}$, number of grains spike ${ }^{-1}$, grain weight spike $^{-1}$, 1000- grain weight and grain yield $\left(\right.$ ard.fed $\left.^{-1}\right)$ were significantly affected by wild oat densities $\mathrm{m}^{-2}$ in both seasons. These parameters were progressively reduced by increasing wild oat density during the two growing seasons. The highest wild oat density ( 25 plants $\mathrm{m}^{-2}$ ) recorded the highest reduction in number of spikes $\mathrm{m}^{-2}$ by 14.8 and $17.9 \%$, number of grains spike ${ }^{-1}$ by 6.4 and 
$6.5 \%$, grain weight spike $^{-1}$ by 28.9 and $31.8 \%$ and 1000 - grain weight by 4.9 and $7.5 \%$ during the first and second seasons, respectively compared with weed free treatment which gave the highest values for these yield components.

Meanwhile increasing wild oat density led to decreasing wheat grain yield. The densities of 5, 10, 15, 20 and 25 wild oat plants $\mathrm{m}^{-2}$ reduced the grain yield by $6.1,11.1,15.6,20.0$ and $25.0 \%$ as compared to zero density of wild oat, respectively. Similar trend was obtained in the second season since the previous wild oat densities decreased wheat grain yield by $8.5,14.3$, 19.6, 24.3 and $28.3 \%$, respectively. It is clear from the previous results that wheat grain yield was sharply affected by wild oat infestation since increasing wild oat infestation caused dramatic reduction in wheat yield feddan $^{-1}$. This is due to the decrease in number of tillers plant $^{-1}$, number of spikes $\mathrm{m}^{-2}$, number of grains spike ${ }^{-1}$, grain weight spike $^{-1}$ and 1000 -grain weight. These results were in harmony with those obtained by Kirkland (1993), AL-Marsafy et al., (1995), Ibrahim et al., (1995), Silvertown and Charlesworth (2001), Mennan and Bozoglu (2004), Cheema and Akhtar (2006), Khan and Hassan (2006), Hassan and Khan (2007) and Khan et al., (2008).

\section{NPK concentration and uptake:}

NPK concentration of wheat and wild oat plants:

Effect of NPK fertilizers.

Generally, N, P and $\mathrm{K}$ concentrations in both wheat and wild oat plants declined by age showing the translocation of the metabolized materials from the shoot to the storage organs. During the three studied growth periods, $\mathrm{N}$ concentration in wild oat plants was higher than that of wheat plants. However, $\mathrm{P}$ content showed the opposite, since $\mathrm{P}$ concentration in wheat plants was higher than that of wild oat plants during the different growth periods. Meanwhile, the same trend of $\mathrm{P}$ was also observed for $\mathrm{K}$ content during the first two periods (30 and 60 DAS) only but during the late growth period (90 DAS), K concentration of wild oat plants was higher than that of wheat plants.

Table 4. Effect of NPK fertilizer rates and wild oat densities on nutrient concentration of wheat and wild oat plants after 30, 60 and 90 days from sowing in 2013/2014 and 2014/2015 seasons.

\begin{tabular}{|c|c|c|c|c|c|c|c|c|c|c|c|c|c|c|c|c|c|c|}
\hline \multirow{3}{*}{ Treatments } & \multicolumn{6}{|c|}{ Nitrogen \% } & \multicolumn{6}{|c|}{ Phosphorus \% } & \multicolumn{6}{|c|}{ Potassium \% } \\
\hline & \multicolumn{3}{|c|}{ Wheat } & \multicolumn{3}{|c|}{ Wild Oat } & \multicolumn{3}{|c|}{ Wheat } & \multicolumn{3}{|c|}{ Wild Oat } & \multicolumn{3}{|c|}{ Wheat } & \multicolumn{3}{|c|}{ Wild Oat } \\
\hline & $\begin{array}{c}\text { 30 } \\
\text { DAS }\end{array}$ & $\begin{array}{c}\text { 60 } \\
\text { DAS }\end{array}$ & $\begin{array}{c}90 \\
\text { DAS }\end{array}$ & $\begin{array}{c}30 \\
\text { DAS }\end{array}$ & $\begin{array}{c}\text { 60 } \\
\text { DAS }\end{array}$ & $\begin{array}{c}90 \\
\text { DAS }\end{array}$ & $\begin{array}{c}\text { 30 } \\
\text { DAS }\end{array}$ & $\begin{array}{c}60 \\
\text { DAS }\end{array}$ & $\begin{array}{c}90 \\
\text { DAS }\end{array}$ & $\begin{array}{c}\text { 30 } \\
\text { DAS }\end{array}$ & $\begin{array}{c}\mathbf{6 0} \\
\text { DAS }\end{array}$ & $\begin{array}{c}90 \\
\text { DAS }\end{array}$ & $\begin{array}{c}30 \\
\text { DAS }\end{array}$ & $\begin{array}{c}60 \\
\text { DAS }\end{array}$ & $\begin{array}{c}90 \\
\text { DAS }\end{array}$ & $\begin{array}{c}30 \\
\text { DAS }\end{array}$ & $\begin{array}{c}60 \\
\text { DAS }\end{array}$ & $\begin{array}{c}90 \\
\text { DAS }\end{array}$ \\
\hline \multicolumn{19}{|c|}{ 2013/2014 season } \\
\hline \multicolumn{19}{|c|}{ A- NPK fertilizers } \\
\hline $\mathrm{N}_{50} \mathrm{P}_{10} \mathrm{~K}_{12}$ & 3.39 & 2.25 & 1.27 & 4.11 & 2.96 & 1.53 & 0.224 & 0.162 & 0.090 & 0.190 & 0.1 & 0.089 & 3.36 & 2.93 & 1.65 & 3.15 & 2.75 & 1.76 \\
\hline $\mathrm{N}_{75} \mathrm{P}_{15} \mathrm{~K}_{24}$ & 3.61 & 3.26 & 1.36 & 4.28 & 3.36 & 1.67 & 0.246 & 0.173 & 0.101 & 0.20 & 0.150 & 0.105 & 3.58 & 3.18 & 1.79 & 3.33 & 2.87 & 1.88 \\
\hline $\mathrm{N}_{100} \mathrm{P}_{20} \mathrm{~K}_{36}$ & 3.90 & 3.48 & 1.45 & 4.71 & 3.93 & 1.88 & 0.257 & 0.182 & 0.129 & 0.226 & 0.157 & 0.110 & 3.65 & 3.34 & 1.87 & 3.44 & 3.08 & 1.93 \\
\hline L.S.D at 0.05 & 0.22 & 0.30 & 0.15 & 0.31 & 0.21 & 0.20 & 0.05 & NS & 0.04 & 0.06 & 0.03 & 0.03 & 0.13 & 0.18 & 0.06 & NS & 0.28 & 0.08 \\
\hline \multicolumn{19}{|c|}{ B- Wild oat density $\mathrm{m}^{-2}$} \\
\hline zero & 4.60 & 3.61 & 1.75 & -- & -- & -- & 0.294 & 0.203 & 0.148 & -- & -- & -- & 4.19 & 3.73 & 2.21 & -- & -- & -- \\
\hline 5 & 3.97 & 3.42 & 1.46 & 5.13 & 3.87 & 2.13 & 0.264 & 0.188 & 0.129 & 0.231 & 0.159 & 0.128 & 3.85 & 3.52 & .92 & 3.73 & 3.49 & 2.09 \\
\hline 10 & 3.64 & 3.19 & 1.38 & 4.91 & 3.56 & 1.94 & 0.241 & 0.172 & 0.111 & 0.222 & 0.150 & 0.109 & 3.71 & 3.33 & 1.75 & 3.49 & 3.13 & 1.98 \\
\hline 15 & 3.29 & 2.88 & 1.29 & 4.52 & 3.39 & 1.66 & 0.217 & 0.161 & 0.098 & 0.202 & 0.142 & 0.095 & 3.53 & 3.21 & .64 & .29 & 3.06 & 1.79 \\
\hline 20 & 3.09 & 2.63 & 1.07 & 4.07 & 3.11 & 1.50 & 0.200 & 0.151 & 0.087 & 0.188 & 0.135 & 0.079 & 3.13 & 3.97 & 1.56 & 3.07 & 2.81 & 1.61 \\
\hline 25 & 2.76 & 2.44 & 1.00 & 3.55 & 2.77 & 1.21 & 0.192 & 0.144 & 0.075 & 0.16 & 0.127 & 0.072 & 2.88 & 2.83 & .41 & 2.91 & 2.45 & 1.47 \\
\hline L.S.D at ${ }_{0.05}$ & 0.18 & 0.11 & 0.15 & 0.23 & 0.18 & 0.11 & 0.02 & NS & 0.01 & 0.02 & NS & 0.01 & 0.14 & 0.12 & 0.07 & 0.23 & 0.21 & 0.12 \\
\hline \multicolumn{19}{|c|}{$2014 / 2015$ season } \\
\hline \multicolumn{19}{|c|}{ A- NPK fertilizers } \\
\hline $\mathrm{N}_{50} \mathrm{P}_{10} \mathrm{~K}_{12}$ & 3.25 & 2.34 & 1.19 & 4.05 & 2.83 & 1.43 & 0.206 & 0.153 & 0.085 & 0.183 & 0.134 & 0.080 & 3.18 & 2.87 & 1.62 & 3.11 & 2.54 & 1.68 \\
\hline $\mathrm{N}_{75} \mathrm{P}_{15} \mathrm{~K}_{24}$ & 3.36 & 3.17 & 1.24 & 4.40 & 3.25 & 1.53 & & 0.164 & $0.0 S$ & 0 . & 0.136 & & 3.46 & 3.11 & 1.66 & .21 & 2.80 & 1.77 \\
\hline $\mathrm{N}_{100} \mathrm{P}_{20} \mathrm{~K}_{36}$ & 3.89 & 3.31 & 1.31 & 4.58 & 3.88 & 1.68 & 0.245 & 0.169 & 0.126 & 0.210 & 0.141 & 0.095 & 3.56 & 3.29 & 1.69 & 3.30 & 3.11 & 1.85 \\
\hline L.S.D at ${ }_{0.05}$ & 0.17 & 0.10 & NS & 0.26 & 0.13 & 0.08 & 0.02 & NS & 0.01 & 0.02 & NS & 0.01 & 0.11 & 0.13 & 0.05 & NS & 0.24 & 0.04 \\
\hline \multicolumn{19}{|c|}{ B- Wild oat density $\mathrm{m}^{-2}$} \\
\hline zero & 4.50 & 3.50 & 1.69 & -- & -- & -- & 0.287 & 0.193 & 0.135 & -- & -- & -- & 4.07 & 3.57 & 2.04 & -- & -- & -- \\
\hline 5 & 3.92 & 3.33 & 1.36 & 5.06 & 3.86 & 2.06 & 0.253 & 0.178 & 0.116 & 0.229 & 90.156 & 0.119 & 3.76 & 3.36 & 1.84 & 3.63 & 3.59 & 2.14 \\
\hline 10 & 3.61 & 3.11 & 1.25 & 4.81 & 3.64 & 1.81 & 0.228 & 0.165 & 0.104 & 0.203 & 30.144 & 0.092 & 3.55 & 3.25 & 1.66 & 3.39 & 3.03 & 1.93 \\
\hline 15 & 3.28 & 2.76 & 1.17 & 4.42 & 3.42 & 1.44 & .205 & 0.155 & 0.0 & 0.192 & 20.137 & 0.0 & 3.36 & 3.04 & 1.56 & 3.18 & 2.80 & 1.74 \\
\hline 20 & 3.03 & 2.56 & 1.00 & 4.03 & 3.03 & 1.31 & 0.195 & 0.143 & 0.084 & 0.18 & 40.130 & 0.071 & 3.00 & 3.85 & 1.51 & 2.98 & 2.51 & 1.58 \\
\hline 25 & 2.67 & 2.38 & 1.00 & 3.42 & 2.67 & 1.14 & 0.180 & 0.135 & 0.071 & 0.168 & 30.119 & 0.065 & 2.67 & 2.48 & 1.35 & 2.85 & 2.15 & 1.42 \\
\hline L.S.D at ${ }_{0.05}$ & 0.15 & 0.10 & 0.13 & 0.21 & 0.15 & 0.09 & 0.02 & 0.01 & 0.01 & 0.02 & 0.01 & 0.01 & 0.12 & 0.12 & 0.06 & 0.22 & 0.19 & 0.07 \\
\hline \multicolumn{19}{|c|}{ Interaction } \\
\hline & NS & NS & NS & NS & NS & & NS & NS & NS & NS & NS & NS & NS & NS & NS & NS & NS & NS \\
\hline $\mathrm{A} \times \mathrm{B}_{2014 / 15}$ & NS & NS & NS & NS & NS & NS & NS & NS & NS & NS & NS & NS & NS & NS & NS & NS & NS & NS \\
\hline
\end{tabular}


Results presented in Table (4) revealed that NPK fertilizers had significantly effect on $\mathrm{N}, \mathrm{P}$ and $\mathrm{K} \%$ of wheat and wild oat plants in various studied growth periods at 30,60 and 90 DAS except $\mathrm{P} \%$ in wheat plant at $60 \mathrm{DAS}$ and $\mathrm{K} \%$ in wild oat plant at $30 \mathrm{DAS}$ in the first season and $\mathrm{N} \%$ in wheat plant at 90 DAS, P \% in wheat and wild oat plants at 60 DAS and $\mathrm{K} \%$ in wild oat plant at 30 DAS in second season. Increasing NPK fertilizers from $\mathrm{N}_{50} \mathrm{P}_{10} \mathrm{~K}_{12}$ to $\mathrm{N}_{100} \mathrm{P}_{20} \mathrm{~K}_{36}$ increased $\mathrm{N}, \mathrm{P}$ and $\mathrm{K} \%$ of wheat and wild oat plants at different growth periods in both seasons. Application of $\mathrm{N}_{100} \mathrm{P}_{20} \mathrm{~K}_{36}$ fertilizer gave the highest values of $\mathrm{N}, \mathrm{P}$ and $\mathrm{K} \%$ of wheat and wild oat plants at the studied growth periods in both seasons compared to $\mathrm{N}_{50} \mathrm{P}_{10} \mathrm{~K}_{12}$ fertilizer. Effect of wild oat density.

Data presented in Table (4) showed that wild oat densities $\mathrm{m}^{-2}$ significantly affected $\mathrm{N}, \mathrm{P}$ and $\mathrm{K} \%$ of wheat and wild oat plants at 30,60 and 90 DAS in both seasons except $\mathrm{P} \%$ in wheat and wild oat plants at 60 in the first season only. The highest values of $\mathrm{N}, \mathrm{P}$ and $\mathrm{K}$ $\%$ in wheat plant at 30,60 and 90 DAS were observed from weed free treatment and the lowest values was

Table 5. Effect of NPK fertilizer rates and wild oat densities on nutrient concentration and uptake by grain

\begin{tabular}{|c|c|c|c|c|c|c|c|}
\hline \multirow{2}{*}{ Treatments } & \multicolumn{3}{|c|}{ Nutrient content $(\%)$} & \multicolumn{3}{|c|}{ Nutrient uptake $\left(\mathrm{kg} \mathrm{fed}^{-1}\right)$} & \multirow{2}{*}{ Protein $\%$} \\
\hline & $\mathbf{N}$ & $\mathbf{P}$ & $\mathbf{K}$ & $\mathbf{N}$ & $\mathbf{P}$ & $\mathbf{K}$ & \\
\hline \multicolumn{8}{|c|}{$2013 / 2014$ season } \\
\hline \multicolumn{8}{|c|}{ A- NPK fertilizer } \\
\hline $\mathrm{N}_{50} \mathrm{P}_{10} \mathrm{~K}_{12}$ & 1.87 & 0.306 & 0.302 & 48.34 & 8.00 & 7.84 & 10.66 \\
\hline $\mathrm{N}_{75} \mathrm{P}_{15} \mathrm{~K}_{24}$ & 2.05 & 0.326 & 0.432 & 59.21 & 9.25 & 12.17 & 11.69 \\
\hline $\mathrm{N}_{100} \mathrm{P}_{20} \mathrm{~K}_{36}$ & 2.11 & 0.398 & 0.439 & 61.79 & 11.79 & 12.91 & 12.03 \\
\hline L.S.D. at ${ }_{0.05}$ & NS & 0.01 & 0.01 & 5.36 & 0.30 & 0.13 & NS \\
\hline \multicolumn{8}{|c|}{ B- Wild oats densities $\mathrm{m}^{-2}$} \\
\hline zero & 2.13 & 0.415 & 0.439 & 67.92 & 13.30 & 14.10 & 12.14 \\
\hline 5 & 2.11 & 0.382 & 0.411 & 63.13 & 11.45 & 12.36 & 12.03 \\
\hline 10 & 2.07 & 0.359 & 0.390 & 58.62 & 10.20 & 11.12 & 11.80 \\
\hline 15 & 2.03 & 0.320 & 0.379 & 54.83 & 8.63 & 10.26 & 11.57 \\
\hline 20 & 1.94 & 0.309 & 0.369 & 49.45 & 7.89 & 9.43 & 11.06 \\
\hline 25 & 1.76 & 0.276 & 0.356 & 44.73 & 6.61 & 8.55 & 10.03 \\
\hline L.S.D. at ${ }_{0.05}$ & 0.23 & 0.02 & 0.01 & 2.87 & 0.51 & 0.37 & 1.31 \\
\hline \multicolumn{8}{|c|}{ 2014/2015 season } \\
\hline \multicolumn{8}{|c|}{ A- NPK fertilizer } \\
\hline $\mathrm{N}_{50} \mathrm{P}_{10} \mathrm{~K}_{12}$ & 1.97 & 0.363 & 0.368 & 50.07 & 9.33 & 9.51 & 11.22 \\
\hline $\mathrm{N}_{75} \mathrm{P}_{15} \mathrm{~K}_{24}$ & 2.16 & 0.401 & 0.483 & 59.70 & 11.17 & 13.51 & 12.29 \\
\hline $\mathrm{N}_{100} \mathrm{P}_{20} \mathrm{~K}_{36}$ & 2.19 & 0.453 & 0.486 & 65.47 & 13.66 & 14.53 & 12.48 \\
\hline L.S.D. at ${ }_{0.05}$ & 0.19 & 0.05 & 0.06 & 1.56 & 1.38 & 1.82 & 0.10 \\
\hline \multicolumn{8}{|c|}{ B- Wild oats densities $\mathrm{m}^{-2}$} \\
\hline zero & 2.15 & 0.443 & 0.521 & 70.85 & 14.68 & 17.08 & 12.26 \\
\hline 5 & 2.10 & 0.468 & 0.454 & 64.28 & 14.07 & 13.78 & 11.97 \\
\hline 10 & 2.09 & 0.409 & 0.476 & 59.64 & 11.61 & 13.48 & 11.91 \\
\hline 15 & 2.04 & 0.395 & 0.428 & 55.50 & 10.50 & 11.40 & 11.63 \\
\hline 20 & 2.00 & 0.369 & 0.415 & 51.70 & 9.22 & 10.38 & 11.40 \\
\hline 25 & 1.96 & 0.349 & 0.379 & 48.53 & 8.25 & 8.97 & 11.17 \\
\hline L.S.D. at ${ }_{0.05}$ & 0.23 & 0.05 & 0.08 & 1.09 & 1.40 & 2.24 & 0.11 \\
\hline \multicolumn{8}{|c|}{ Interactions } \\
\hline $\mathrm{A} \times \mathrm{B}_{2013 / 2014}$ & NS & NS & NS & NS & NS & NS & NS \\
\hline $\mathrm{A} \times \mathrm{B}_{2014 / 2015}$ & NS & NS & NS & NS & NS & NS & NS \\
\hline
\end{tabular}

obtained from density of 25 wild oat plants $\mathrm{m}^{-2}$ in both seasons. While, the maximum $\mathrm{N}, \mathrm{P}$ and $\mathrm{K} \%$ in wild oat at 30, 60 and 90 DAS were obtained from density of 5 wild oat plants $\mathrm{m}^{-2}$ and the lowest values was observed from density of 25 wild oat plants $\mathrm{m}^{-2}$ in both seasons.

\section{NPK concentration and uptake in wheat grain:}

Effect of NPK fertilizers.

Significant increases in N, P and K uptake in wheat grains were noticed by increasing NPK rate to $\mathrm{N}_{75} \mathrm{P}_{15} \mathrm{~K}_{24}$ and $\mathrm{N}_{100} \mathrm{P}_{20} \mathrm{~K}_{36}$ in favor of the higher rate which gave significant increase in $\mathrm{N}, \mathrm{P}$ and $\mathrm{K}$ uptake by $27.8,47.4$ and $64.7 \%$, respectively in the first season and by 30.8 , 46.4 and $52.8 \%$, respectively in the second season. There were no significant differences between $\mathrm{N}_{75} \mathrm{P}_{15} \mathrm{~K}_{24}$ and $\mathrm{N}_{100} \mathrm{P}_{20} \mathrm{~K}_{36}$ in most cases. Worth mentioning the N, P and $\mathrm{K}$ percentages in wheat grain followed the same trend observed with $\mathrm{N}, \mathrm{P}$ and $\mathrm{K}$ uptake. On the other hand, protein \% was not significantly affected by NPK treatments in the first season while it was significantly augmented by increasing NPK rate in the second season as shown in Table (5).

\section{wheat in 2013/ 2014 and 2014/ 2015 seasons.}


In this regard, El- Kouny (2007) indicated that increased mineral fertilizer significantly increased crude protein, phosphorus and potassium percentage in wheat grains. Auti et al., (1996) reported that grain and straw yield, grain protein content and $\mathrm{N}$ and $\mathrm{K}$ uptake increased with increasing fertilizer rate. Sharshar and Soad El- Said (2000) showed that optimum NPK fertilizer enhanced growth and yield and nutrient uptake in wheat. These results are in line with Laghari et al., (2010).

Effect of wild oat density.

As shown in Table (5) N, P and K percentages or uptake as well as grain protein percentage were reduced by increasing wild oat density and the highest density ( 25 wild oat plants $\mathrm{m}^{-2}$ ) recorded the highest reduction by $17.4,33.5$ and $18.9 \%$ for $\mathrm{N}, \mathrm{P}$ and $\mathrm{K} \%$, respectively compared with weed free treatment in the first season and by 8.8, 21.2 and $27.3 \%$, respectively in the second season. The corresponding values for $\mathrm{N}, \mathrm{P}$ and $\mathrm{K}$ uptake were $34.1,50.3$ and $39.4 \%$, respectively in the first season and $31.5,43.8$ and $47.5 \%$, respectively in the second season. Protein content of wheat grain took the same trend since the highest wild oat density ( 25 plants $\mathrm{m}^{-2}$ ) reduced it by 17.4 and $8.9 \%$ during the first and second seasons, respectively compared with zero wild oat plants $\mathrm{m}^{-2}$. These results suggest that wild oat compete strongly with wheat crop for main macro nutrients especially with nitrogen. Similar results were obtained by Khan et al., (2007) and Khan et al., (2008).

4- The effect of interaction between NPK fertilizer rates and wild oat densities:

The data in Table (6) revealed that all interaction between NPK fertilizers and wild oat densities had statically significant effect on wheat dry weight at 80 and 120 DAS, number of spikes $\mathrm{m}^{-2}$ and grain yield $\left(\operatorname{ard.fed}^{-1}\right)$ in both seasons and number of tillers plant ${ }^{-1}$, weight grains spike ${ }^{-1}$ and 1000- grain weight in second season. The maximum wheat dry weight at 80 DAS $(920.9 \mathrm{~g})$ and $120(1870.0 \mathrm{~g})$ were recorded from weed free treatment with $\mathrm{N}_{100} \mathrm{P}_{20} \mathrm{~K}_{36}$ fertilizer and the minimum wheat dry weight at 80 DAS $(378.8 \mathrm{~g})$ and $120(1200.2 \mathrm{~g})$ were recorded from 25 wild oat plants $\mathrm{m}^{-2}$ with $\mathrm{N}_{50} \mathrm{P}_{10} \mathrm{~K}_{12}$ fertilizer, respectively in the first season. In the second season, the highest wheat dry weight at 80 DAS (1043.4 g) and $120(2021.1 \mathrm{~g})$ were recorded from weed free treatment with $\mathrm{N}_{100} \mathrm{P}_{20} \mathrm{~K}_{36}$ fertilizer and the lowest wheat dry weight at 80 DAS $(521.5 \mathrm{~g})$ and $120(1281.4 \mathrm{~g})$ were recorded from 25 wild oat plants $\mathrm{m}^{-2}$ with $\mathrm{N}_{50} \mathrm{P}_{10} \mathrm{~K}_{12}$ fertilizer, respectively.

Table 6. Effect of interaction between NPK fertilizer rates and wild oat densities on growth, yield and yield components of wheat in 2013/2014 and 2014/2015 seasons.

\begin{tabular}{|c|c|c|c|c|c|c|c|c|c|c|}
\hline \multicolumn{2}{|c|}{ Treatments } & \multicolumn{3}{|c|}{ 2013/2014 season } & \multicolumn{6}{|c|}{$2014 / 2015$ season } \\
\hline $\begin{array}{l}\text { NPK } \\
\text { fertilizers }\end{array}$ & $\begin{array}{c}\text { Wild oat } \\
\text { densities } \\
(\text { plants } \\
\left.\text { m }^{-2}\right)\end{array}$ & $\begin{array}{c}\text { Wheat dry } \\
\text { weight at } 80 \\
\text { DAS } \\
\left(\mathrm{g} \mathrm{m}^{-2}\right)\end{array}$ & $\begin{array}{l}\text { Wheat dry } \\
\text { weight } \\
\text { at } 120 \text { DAS } \\
\left(\mathrm{g} \mathrm{m}^{-2}\right)\end{array}$ & $\begin{array}{l}\text { No. of } \\
\text { spikes } \\
\text { m }^{-2}\end{array}$ & $\begin{array}{c}\text { Wheat dry } \\
\text { weight at } \\
\text { 80 DAS } \\
\left(\mathrm{g} \mathrm{m}^{-2}\right)\end{array}$ & $\begin{array}{c}\text { Wheat dry } \\
\text { weight at } \\
120 \text { DAS } \\
\left(\mathrm{g} \mathrm{m}^{-2}\right)\end{array}$ & $\begin{array}{l}\text { No. of } \\
\text { tillers } \\
\text { plant }^{-1}\end{array}$ & $\begin{array}{l}\text { Weight } \\
\text { grains } \\
\text { spike } \\
\text { (g) }\end{array}$ & $\begin{array}{c}\text { No. of } \\
\text { spikes } \\
\text { m }^{-2}\end{array}$ & $\begin{array}{l}\text { 1000- } \\
\text { Grain } \\
\text { weight } \\
\text { (g) }\end{array}$ \\
\hline \multirow{6}{*}{$\mathrm{N}_{50} \mathrm{P}_{10} \mathrm{~K}_{12}$} & Zero & 607.8 & 1461.8 & 396.0 & 674.5 & 1558.6 & 2.73 & 3.80 & 383.0 & 48.7 \\
\hline & 5 & 572.1 & 1415.7 & 356.0 & 652.8 & 1530.7 & 2.80 & 3.27 & 364.7 & 48.0 \\
\hline & 10 & 504.6 & 1384.1 & 344.3 & 597.3 & 1496.2 & 2.57 & 2.97 & 354.7 & 47.9 \\
\hline & 15 & 459.4 & 1331.1 & 349.3 & 575.8 & 1438.0 & 2.57 & 3.13 & 358.3 & 47.3 \\
\hline & 20 & 410.6 & 1258.2 & 327.7 & 533.8 & 1387.8 & 2.47 & 2.77 & 348.3 & 46.8 \\
\hline & 25 & 378.8 & 1200.2 & 325.7 & 521.5 & 1281.4 & 2.43 & 2.43 & 342.0 & 46.2 \\
\hline \multirow{6}{*}{$\mathrm{N}_{75} \mathrm{P}_{15} \mathrm{~K}_{24}$} & Zero & 743.6 & 1643.4 & 461.3 & 853.3 & 1843.3 & 3.10 & 4.33 & 475.7 & 50.3 \\
\hline & 5 & 692.9 & 1563.6 & 436.7 & 835.2 & 1762.5 & 3.03 & 4.37 & 459.3 & 50.0 \\
\hline & 10 & 627.2 & 1503.4 & 423.7 & 815.2 & 1691.9 & 2.87 & 3.80 & 445.0 & 49.2 \\
\hline & 15 & 558.8 & 1400.3 & 416.7 & 783.3 & 1643.7 & 2.87 & 3.70 & 437.3 & 48.4 \\
\hline & 20 & 536.3 & 1339.3 & 399.0 & 742.2 & 1564.8 & 2.77 & 3.67 & 310.3 & 47.7 \\
\hline & 25 & 485.8 & 1310.2 & 390.3 & 705.3 & 1539.7 & 2.63 & 3.07 & 415.0 & 46.8 \\
\hline \multirow{6}{*}{$\mathrm{N}_{100} \mathrm{P}_{20} \mathrm{~K}_{36}$} & Zero & 920.9 & 1870.0 & 475.0 & 1043.4 & 2021.1 & 3.43 & 5.10 & 495.3 & 53.1 \\
\hline & 5 & 878.5 & 1731.4 & 467.3 & 997.6 & 1921.1 & 3.30 & 4.90 & 479.7 & 51.9 \\
\hline & 10 & 799.3 & 1669.5 & 447.0 & 937.0 & 1848.7 & 3.23 & 4.90 & 464.7 & 50.8 \\
\hline & 15 & 740.4 & 1571.7 & 438.0 & 875.2 & 1738.9 & 3.00 & 4.00 & 463.0 & 49.9 \\
\hline & 20 & 670.1 & 1484.3 & 416.3 & 843.0 & 1697.0 & 2.77 & 3.70 & 453.3 & 48.8 \\
\hline & 25 & 612.1 & 1421.8 & 396.3 & 780.6 & 1629.0 & 2.60 & 3.40 & 449.0 & 47.7 \\
\hline \multicolumn{2}{|c|}{ L.S.D. at ${ }_{0.05}$} & 29.7 & 60.5 & 63.0 & 47.2 & 52.8 & 0.17 & 0.47 & 123.0 & 0.84 \\
\hline
\end{tabular}

For the interaction of NPK fertilizer with wild oat densities, the maximum (475.0 and 495.3) number of spikes $\mathrm{m}^{-2}$ were recorded from weed free treatment with $\mathrm{N}_{100} \mathrm{P}_{20} \mathrm{~K}_{36}$ fertilizer, and the minimum number of spikes $\mathrm{m}^{-2}$ (325.7 and 342.0) were recorded from 25 wild oat plants $\mathrm{m}^{-2}$ with $\mathrm{N}_{50} \mathrm{P}_{10} \mathrm{~K}_{12}$ fertilizer, respectively in both seasons. The maximum number of tillers plant ${ }^{-1}(3.43)$, weight grains $\operatorname{spike}^{-1}(5.10 \mathrm{~g})$ and 1000 - grain weight 
$(53.1 \mathrm{~g})$ were recorded from weed free treatment with $\mathrm{N}_{100} \mathrm{P}_{20} \mathrm{~K}_{36}$ fertilizer, and the minimum number of tillers plant $^{-1}(2.43)$, weight grains $\operatorname{spike}^{-1}(2.43 \mathrm{~g})$ and 1000 grain weight $(46.2 \mathrm{~g})$ were recorded from 25 wild oat plants $\mathrm{m}^{-2}$ with $\mathrm{N}_{50} \mathrm{P}_{10} \mathrm{~K}_{12}$ fertilizer, respectively in second season only.

\section{5- Prediction of wheat grain yield losses due to wild} oat competition

It was clear that the suitable model which fitted for prediction wheat grain yield $\left(\operatorname{ard}\right.$ fed $\left.{ }^{-1}\right)$ losses was quadratic regression because the correlation coefficient $\left(\mathrm{R}^{2}\right)$ was greater than other studied models and standard estimate error (SE) were smaller than those of the polynomial models were: $\hat{Y}=19.30-0.17 \mathrm{x}+0.021 \mathrm{x}^{2}$
$\mathrm{R}^{2}=0.999, \hat{\mathrm{Y}}=21.24-0.21 \mathrm{x}+0.001 \mathrm{x}^{2} \quad \mathrm{R}^{2}=0.997$ and $\hat{Y}=22.88-0.33 x+0.003 x^{2} R^{2}=0.997$ due to the increasing wild oat densities from zero to 25 plants $\mathrm{m}^{-2}$ under $\mathrm{N}_{50} \mathrm{P}_{10} \mathrm{~K}_{12}, \mathrm{~N}_{75} \mathrm{P}_{15} \mathrm{~K}_{24}$ and $\mathrm{N}_{100} \mathrm{P}_{20} \mathrm{~K}_{36}$, respectively in the first season and $Y=19.60-0.30 \mathrm{x}+0.005 \mathrm{x}^{2}-$ $\mathrm{R}^{2}=0.997, \hat{\mathrm{Y}}=21.74-0.33 \mathrm{x}+0.003 \mathrm{x}^{2}-\mathrm{R}^{2}=0.999$ and $\hat{Y}=24.11-0.42 \mathrm{x}+0.004 \mathrm{x}^{2}-\mathrm{R}^{2}=0.997$ under $\mathrm{N}_{50} \mathrm{P}_{10} \mathrm{~K}_{12}, \mathrm{~N}_{75} \mathrm{P}_{15} \mathrm{~K}_{24}$ and $\mathrm{N}_{100} \mathrm{P}_{20} \mathrm{~K}_{36}$, respectively in the second season. The regression of wheat grain yield on wild oat densities across the different NPK fertilizers (Table 7 and Figure1) showed that increasing wild oat density caused a significant reduction in grain yield $\left(\operatorname{ard} . \mathrm{fed}^{-1}\right)$.

Table 7: Effect of interaction between NPK fertilizer rates and wild oat densities on observed and predicted yield and yield losses of wheat in 2013/2014 and 2014/2015 seasons.

\begin{tabular}{|c|c|c|c|c|c|c|c|}
\hline \multicolumn{2}{|c|}{ Treatments } & \multicolumn{3}{|c|}{$2013 / 2014$ season } & \multicolumn{3}{|c|}{$2014 / 2015$ season } \\
\hline $\begin{array}{l}\text { NPK } \\
\text { fertilizers }\end{array}$ & $\begin{array}{c}\text { Wild oat } \\
\text { densities } \\
\text { (plants } \mathbf{m}^{-2} \text { ) }\end{array}$ & $\begin{array}{l}\text { Observed } \\
\text { grain yield } \\
\text { ard.fed }^{-1}\end{array}$ & $\begin{array}{c}\text { Predicted } \\
\text { grain yield } \\
\text { ard.fed }^{-1}\end{array}$ & $\begin{array}{c}\text { Yield } \\
\text { losses } \\
\%\end{array}$ & $\begin{array}{c}\text { Observed } \\
\text { grain yield } \\
\text { ard.fed }^{-1}\end{array}$ & $\begin{array}{l}\text { Predicted } \\
\text { Grain yield } \\
\left(\text { ard.fed }^{-1}\right)\end{array}$ & $\begin{array}{c}\text { Yield } \\
\text { losses } \\
\%\end{array}$ \\
\hline \multirow{5}{*}{$\mathrm{N}_{50} \mathrm{P}_{10} \mathrm{~K}_{12}$} & Zero & 19.33 & 19.30 & 0.0 & 19.67 & 19.60 & 0.0 \\
\hline & 5 & 18.40 & 18.45 & 4.4 & 18.10 & 18.23 & 7.0 \\
\hline & 10 & 17.63 & 17.60 & 8.8 & 17.03 & 17.10 & 12.8 \\
\hline & 15 & 16.80 & 16.75 & 13.2 & 16.17 & 16.23 & 17.2 \\
\hline & 20 & 16.00 & 15.91 & 17.6 & 15.67 & 15.60 & 20.4 \\
\hline \multirow{7}{*}{$\mathrm{N}_{75} \mathrm{P}_{15} \mathrm{~K}_{24}$} & 25 & 15.10 & 15.06 & 22.0 & 15.03 & 15.23 & 22.3 \\
\hline & Zero & 21.33 & 21.24 & 0.0 & 21.77 & 21.74 & 0.0 \\
\hline & 5 & 20.00 & 20.22 & 4.8 & 20.13 & 20.17 & 7.2 \\
\hline & 10 & 19.23 & 19.24 & 9.4 & 18.83 & 18.74 & 13.8 \\
\hline & 15 & 18.23 & 18.32 & 13.8 & 17.57 & 17.47 & 19.6 \\
\hline & 20 & 17.20 & 17.44 & 17.9 & 16.60 & 16.34 & 24.8 \\
\hline & 25 & 16.20 & 16.62 & 21.8 & 15.63 & 15.37 & 29.3 \\
\hline \multirow{6}{*}{$\mathrm{N}_{100} \mathrm{P}_{20} \mathrm{~K}_{36}$} & Zero & 22.93 & 22.88 & 0.0 & 24.23 & 24.11 & 0.0 \\
\hline & 5 & 21.30 & 21.31 & 6.9 & 21.90 & 22.11 & 8.3 \\
\hline & 10 & 19.67 & 19.88 & 13.1 & 20.40 & 20.31 & 15.8 \\
\hline & 15 & 18.77 & 18.61 & 18.7 & 19.03 & 18.71 & 22.4 \\
\hline & 20 & 17.60 & 17.48 & 23.6 & 17.43 & 17.31 & 28.2 \\
\hline & 25 & 16.50 & 16.51 & 27.8 & 16.40 & 16.11 & 33.2 \\
\hline L.S.D. at ${ }_{0.05}$ & & 0.44 & -- & -- & 0.54 & -- & -- \\
\hline
\end{tabular}

Data also, showed that wheat yield losses $\%$ was increased by increasing NPK fertilizer levels from $\mathrm{N}_{50} \mathrm{P}_{10} \mathrm{~K}_{12}$ up to $\mathrm{N}_{100} \mathrm{P}_{20} \mathrm{~K}_{36}$ and wild oat density from 5 up to 25 wild oat plants $\mathrm{m}^{-2}$ in both seasons. It is clearly indicated from the Figure (1) wheat crop don't compete at higher levels of NPK fertilizer and wild oat densities and there is a drastic decline in grain yield. These results are in agreement with Ahmadvand et al., (2002), Mennan (2003), Harrison et al., (2001), Khan et al., (2007) and El- Nass (2010). 
Fakkar, A.A. et al.
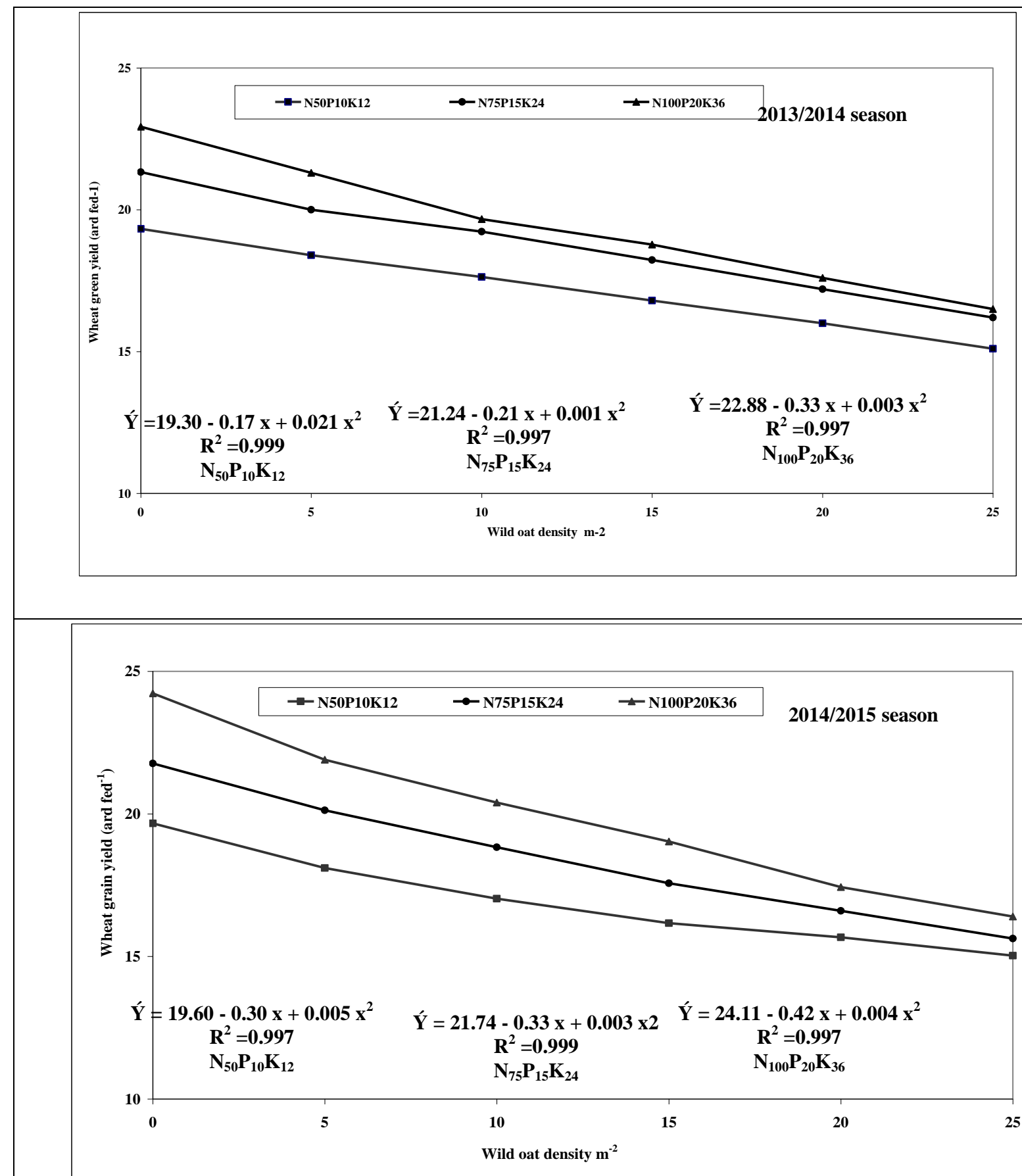

Figure 1. Relationship between wild oat densities and wheat grain yield $\left(\right.$ ard. $^{\text {fed }}{ }^{-1}$ ) under three NPK fertilizer rates.

\section{REFERENCES}

Ahmadvand, G.; A. Koochekiand and M.N. Mahallati (2002). Competitive response of winter wheat (Triticum aestivum) to various plant densities of wild oat (Avena ludoviciana) and nitrogen fertilizer. Agric. Sci. and Tech. 16: 113-124.

AL-Marsafy, H.T.; A.N.M. Nassar; A.A. Esmail and A.A. Fakkar (1995). Effect of weed/Wheat competition on Wheat. Nile Valley Regional Program for Wild Oats Control in Cereals and Some Other Winter Crops. 3 rd Ann., Meet. 1014 Sept., Cairo, Egypt P.P: 184-185.
A.O.A.C. (1990). Official Methods of Analysis. $15^{\text {th }}$ Ed., Association of Official Analytical Chemists, Inc., Virginia, USA, pp: 770-771.

Auti, A. K.; S. C. Wadile and V. S. Rawar (1996). Yield quality and nutrient removal of wheat as influenced by levels and sources of fertilizer. Indian J. Agron., 4: 119- 122.

Black, C. A. (1965). "Methods of Soil Analysis ". Amer. Soc. of Agron. Madison, Wisconsin, U.S.A.

Carlson, H. L. and J. E. Hill. (1985) Wild oat (Avena fatua) competition with spring wheat: effects of nitrogen fertilization. Weed Sci. 34: 29- 33. 
Cheema, M.S. and M. Akhtar (2006) Evaluation of economic threshold level of wild oat (Avena fatua L.) in wheat under super imposed application of fenoxaprop-p-ethyl. Pakistan J. of Weed Sci. Res. 12: 257-264.

Cudney, D.W; L.S. Jordan and A.E. Hall. (1991). Effect of wild oat (Avena fatua) infestations on light interception and growth rate of wheat (Triticum aestivum). Weed Sci. 39: 175-179.

Dhima, K. V. and I. G. Eleftherohorinos (2001) Influence of nitrogen on compétition between Winter cereals and stérile oat. Weed Sci. 49:7782.

El- Kouny, H. M. (2007). Effect of organic manure and biofertilizers on wheat grown in lacutrine soil as compared with mineral fertilizers. Egypt J. Soil Sci., 47 (3): 263- 280.

El-nass, M.K. M. (2010). Estimation of the critical period for weed control and yield losses due to weed competition in wheat and maize. Ph. D. Thesis., Fac. Agric. Alexandria Univ., Egypt.

Freed, R.; S. P. Einensmith; S. Gutez; D. Reicosky; V. W. Smail and P. Wolberg (1989). User's Guide to MSTAT-C: A Software Program for the Design, Management and Analysis of Agronomic Research Experiments Michigan State University, East Lansing, ML, USA.

Gomez, K.A. and A.A. Gomez (1984). Split plot design analysis. In: Statistical procedures for agricultural research. 2nd Ed., John Willey and Sons, New York, USA.

Harrison, S.K.; E. E. Regnier; J. T. Schmoll and J.E. Webb (2001). Competition and fecundity of giant ragweed in corn. Weed Sci.49: 224-229.

Hassan, G. and H. Khan (2007) Effect of wild oats (avena fatua L.) density on wheat yield and its components under varying nitrogen regimes. Pak. J. Bot., 39 (7): 2585-2594.

Ibrahim, H.M.; A.S. Kholosy; M.K. Zahran and E.E. Hassanein (1995). Study of wild oat (Avena fatua) competition with wheat (Triticum $s p$ ). Annals of Agri. Sci. Cairo, 40 (2): 683-696.

Jackson, M.L. (1973). "Soil Chemical Analysis ". Prentice Hall of Indian, Private- Limited New Delhi.

Khan, I.; G. Hassan; M. I. Khan and M. Gul (2007). Effect of wild oat (Avena fatua L.) population and nitrogen levels on some agronomic traits of spring wheat (Triticum aestivum L). Turk. J. Agric., 31: 91-101.

Khan, I. A. and G. Hassan (2006). Effect of wild oats (avena fatua) densities and proportions on yield and yield components of wheat. Pak. J. Weed Sci. Res. 12(1-2): 69-77.

Khan, I.A.; G.I. Hassan and K. B. Marwat (2008). Interaction of wild oats (Avena. fatua) with spring wheat (Triticum aestivim L.) seeded at different rate. Pak. J. Botech. 40 (3): 1163-1167.
Kirkland, K. J. (1993). Spring wheat (Triticum aestivum L.) growth and yield as influenced by duration of wild oat (Avena fatua) competition. Weed Technol. 7: 890-893.

Laghari, G. M.; F. C. Oad.; Sh. Tunio; A. W. Gandahi; M. H. Siddiqui; A. W. Jagirani and S. M. Oad (2010) Growth, yield and nutrient uptake of various wheat cultivars under different fertilizer regimes. Sarhad J. Agric., 26 (4): 490- 497.

Malghani, A. L.; A. U. Malik.; A. Sattar; F. Hussain; G. Abbas and J. Hussain (2010). Response of growth and yield of wheat to NPK fertilizer. Sci. Int. (Lahore), 24 (2): 185-189.

Makowski, R.M.D. (1995). Malva pusila and Avena fatua interference in spring wheat (Triticum aesüvum) and lentils (Lens culinans) in Saskatchewan. Weed Sci. 43: 38-388.

Mennan, H. (2003) Economic thresholds of Sinapis arvensis (wild mustard) in winter wheat fields. J. Argon. 2: 34-39.

Mennan, H. M. and D. I. Bozoglu (2004) Economic thresholds of Avena spp. and Alopecurus myosuroides in winter wheat fields. Pakistan J. Bot. 35: 147-154.

Mohammaddoust, H.R.; A.M. Tulikov and M.A. Baghestani (2006). Effect of Long-term fertilizer application and crop rotation on the infestation of fields by weed. Pak. J. Weed Sci. Res., 12(3): 221-234.

Shahram, L.; P. Parchami and A. Modhej (2011). Study the effects of nitrogen Levels and wild Oat (Avena ludoviciana L.) densities on grain yield and agronomic nitrogen efficiency of wheat (Triticum aestivum L.). Advances in Environ. Biology, 5 (8): 2445-2450.

Sharshar, M.S. and A. Soad El-Said (2000). Evaluation of some wheat cultivars and lines under low and high inputs. J. Agric. Sci. Mansoura Univ. 25(6): 3109-3127.

Silvertown, J. and D. Charlesworth (2001). Intraspecific interactions. 93-121. In Introduction to plant population biology. Blackwell Sci., Oxford, U.K.

Snedecor, G.W. and Cochran, W.G. (1989). Statistical Methods. 8th edition. Iowa State Unvi. Press, Amer, Iowa, USA.

Tkachuk, R. (1966). Note on the nitrogen to protein conversion factor for wheat flour. Cereals Chem., 43: 223-225.

Tariq, J.M.T.; M. Arif; H. Akbar and S. Ali (2007) Response of wheat to source, type and time of nitrogen application. Sarhad J. Agric. 23 (4): 871-879.

Walia, U.S.; K.B. Dhaliwal and L.S. Brar. (1998). Competitive interaction between wheat and wild oat in relation to wild oat population density. In: conference towards sustainable development Chandigarh, India, 15-17 Nov. pp.430-34.

Zimdahl, R.L. (2004). Weed Crop Competition. Areview. Blackwell Publishing., pp: 220. 
Fakkar, A.A. et al.

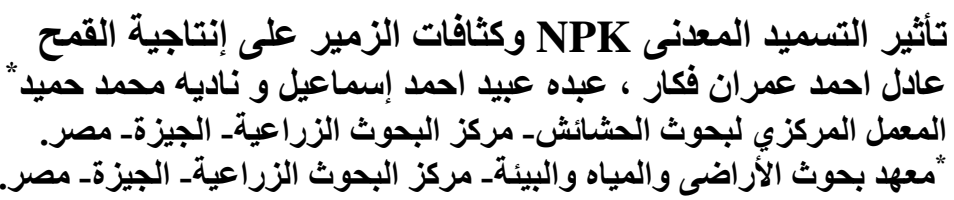

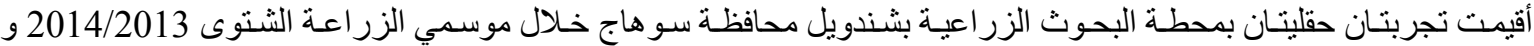

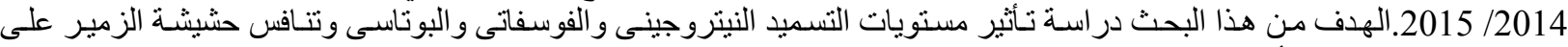

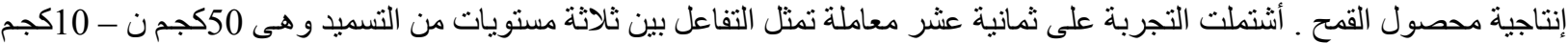

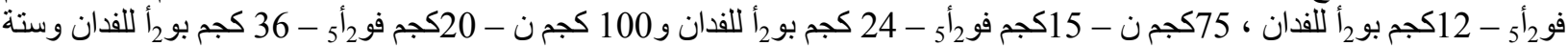

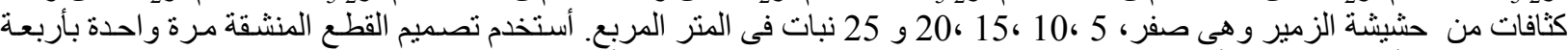

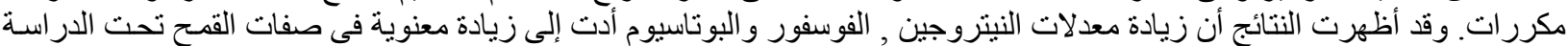

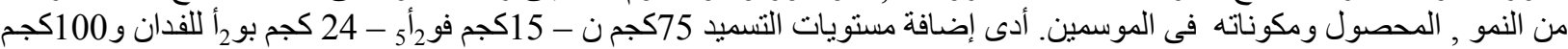

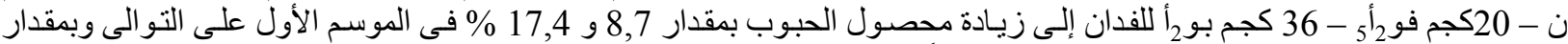

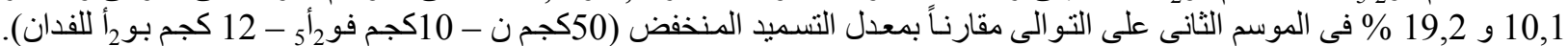

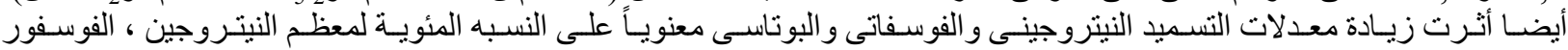

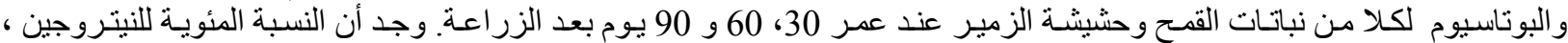

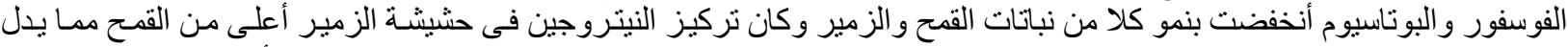

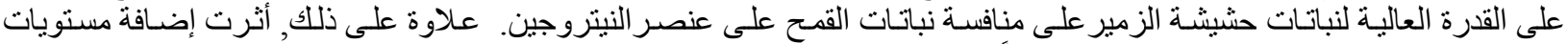

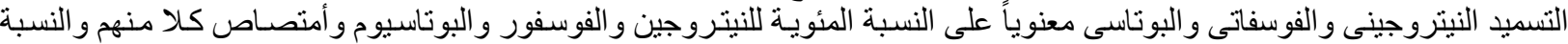

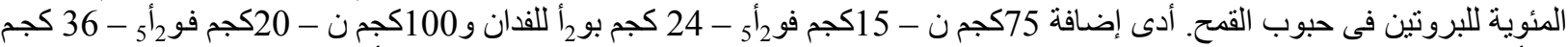

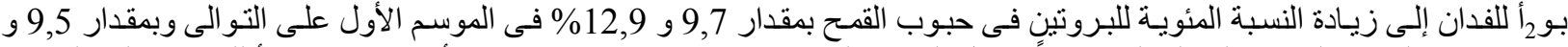

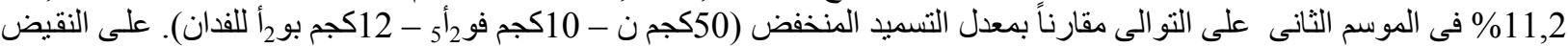

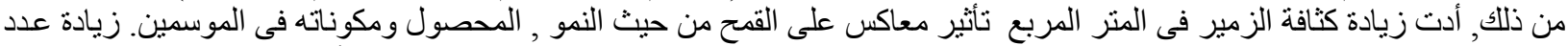

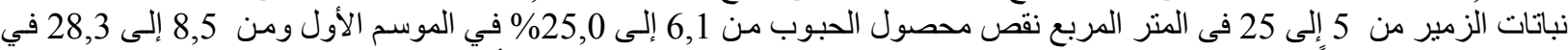

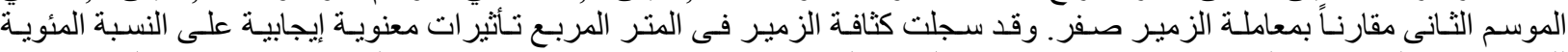

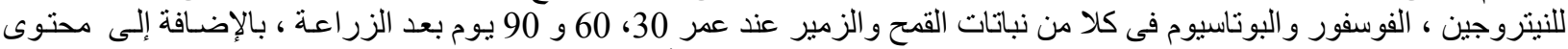

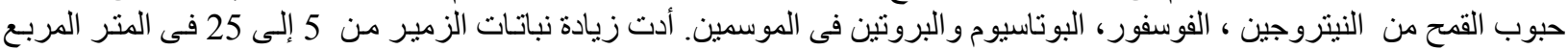

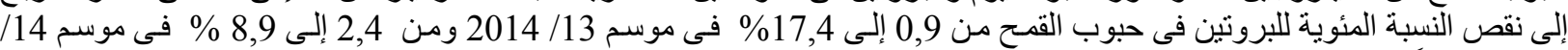

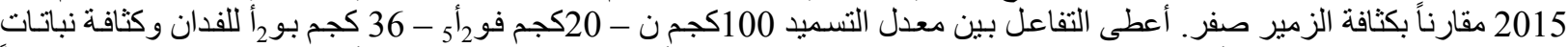

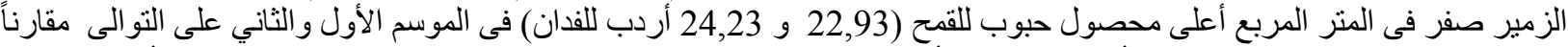

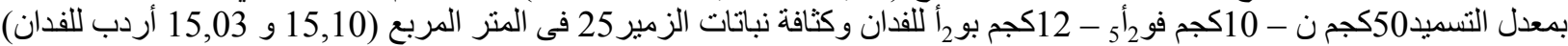

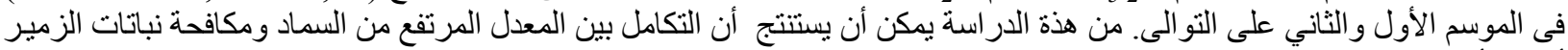
أعطى أعلى محصول حبوب وبروتين للقيح. 